\title{
Tax Dispute Analysis In The Perspective Of Web-Based Tax Audit And Collection PEM
}

\author{
Joni, S.S.T, BKP \\ Institut STIAMI \\ DOI: 10.29322/IJSRP.11.07.2021.p11586 \\ http://dx.doi.org/10.29322/IJSRP.11.07.2021.p11586
}

\begin{abstract}
This study aims to uncover and explore new meanings about tax disputes from the perspective of the parties directly involved, namely the Tax Auditor. Phenomenology is also used as a research method to explore the meaning. The results of the study reveal that the essence of the meaning of tax disputes from the perspective of the Tax Auditor is included in "unfinished negotiations". These "negotiations" manifest themselves in various forms of efforts to obtain "agreements". It does not only appear in the form of differences of opinion that are "material" and "formal" in taxation, but also in the form of rational considerations of profit and loss and efforts to fight for the principle of "justice". The author uses the unified modeling language (UML) as a design tool. The tools needed in designing this system application are using the Hypertext Pre-Processor (PHP) language, and Xampp which already includes Apache, MySQL, PHP. With the Tax Dispute Power of Attorney System (SKSP) it is hoped that it can assist in improving performance in the management of mail services. Managers can check correspondence data at any time and view correspondence reports because there is no need to record one by one, besides finding information about tax dispute correspondence files in the tax court quickly and easily.
\end{abstract}

Index Terms- Tax Disputes, Tax Auditor, Phenomenology, Web

\section{INTRODUCTION}

$\mathrm{T}$ echnology is currently developing so rapidly, various information systems allow processing of data and reports to work quickly, the variety of uses of various information systems causes all life to change with the help of existing systems and many organizations consider information systems necessary to have the ability to compete or gain competitive advantage while the understanding of information systems is the arrangement of people, data, processes and information technology that interact to collect, process, store and provide as output information needed to support an organization.

Likewise with tax issues, at first if there was a dispute between the people and state instruments, it was generally resolved by the District Court (General), the results were not satisfactory, because the dispute occurred in the field of state administration. However, after the enactment of Law No. 5 of 1986, the matter became the authority of the State Administrative Court/State Administrative Court.

Tax dispute is a term used in the taxation system in Indonesia to describe a conflict or difference of opinion on tax issues between the Taxpayer (WP) and the Directorate General of Taxes
(DGT) as the tax authority. Tax disputes often arise as an issue that is always interesting to discuss in the context of taxation. Tax disputes are tax issues that often cause various kinds of controversies Pratama, G. (2020). This is evidenced by the many cases of taxation associated with the issue of tax disputes in Indonesia.

In tax disputes, preventive legal protection is carried out by filing objections to the official who issued the Tax Assessment Letter. Objections are submitted in writing in the Indonesian language by stating the amount of tax payable, the amount of tax withheld or collected or the amount of loss according to the calculation of the taxpayer within 3 (three) months from the date of sending the tax assessment letter or from the date of withholding or collecting the tax as referred to in paragraph (1). in paragraph (1) Article 25 of Law Number 16 of 2009 concerning General Provisions and Tax Procedures Yostiawan, L. (2020), except if the taxpayer can show that the period cannot be fulfilled due to circumstances beyond his control, accompanied by valid reasons. be the basis for the calculation. Objections must be filed. One example of a case related to the settlement of tax disputes that had caught the public's attention was the case of the "tax mafia" Gayus Tambunan in 2010 Yunus, R. M., \& Cartinah, T. (2018, October). In carrying out the activities of incoming mail and tax dispute returns in the tax court, the system is still manual and the data management is still conventional (paper-based). So that the running system has several drawbacks, namely; First, it is difficult for employees of the ICT department to find information regarding incoming letter data and return letters, what is the return letter for, whether the letter has been disputed, and where the disputed letter data is or not. Second, the length of time required by the employee to find the letter has been entered and has a dispute or not. Third, the staff of the ICT department must first request documents from the administration to file a disputed letter of dispute or not, then the person in charge must ask for a signature and submit a letter to return the dispute to the ICT department. Fourth, data processing is still manual (paper-based), prone to errors and data loss because it is recorded in sheet form. Fifth, data management which is still manual (paper-based), also results in the making of incoming mail reports and dispute returns cannot be made quickly. Because to make a report, the ICT department must recap the dispute letter data and the return from the registration form.

A tax dispute is a "legal legal space" created by the Government of the Republic of Indonesia in ensuring the realization of justice and legal certainty for the disputing parties. However, in practice, various kinds of controversies have arisen in practice. Controversy that often raises various kinds of 
questions and perceptions among the wider community. Starting from the question why the tax dispute occurred? What exactly is the object of a tax dispute? What reasons are used to win a tax dispute? These various kinds of questions seem to make tax disputes a social phenomenon in Indonesian society.

Several researchers who have conducted research on tax disputes include: Adhyaputra, A. D. (2020), Pratama, G. (2020), and Adhyaputra, A. D. (2020). Adhyaputra, A. D. (2020) chose to conduct research using a quantitative approach, while Adhyaputra, A. D. (2020) and Pratama, G. (2020), in their research prefer to use a qualitative approach. Syamsuddin, S. (2021) in their research discuss the relationship between accounting conservatism and tax disputes. Based on the results of both studies, it was found that accounting conservatism had a positive impact on the emergence of income tax disputes. Syamsuddin, S. (2021) also added in the results of their research that tax disputes arise due to differences in interests and differences in regulations regarding the recognition of income and expenses. The question that arises for the researcher is if the object of the tax dispute is a difference of opinion on tax regulations, why then between the WP and the DGT seem to have the same "opportunity" to win?; Are there still gaps in the tax dispute process "compromise" and "negotiation" that the parties involved in the tax dispute process are trying to exploit? Usman, S., \& Lana, B. (2019) and Purnamasari, R., Meutia, I., \& Yuniartie, E. (2018) in their research both describe the causes of tax disputes from tax audit actions. According to the study, tax disputes occur because of differences in interpretation and treatment between commercial accounting and fiscal accounting. So the question arises, does the tax dispute occur only because of differences in the interpretation of commercial accounting and tax provisions?

Technically, the presentation of financial statements is not regulated in detail in the tax provisions. However, the measurement and assessment of a fact will be greatly influenced by tax provisions Ambarwati, D., \& Senduk, M. F. (2019). Tax provisions in the form of laws or other regulations under them are legislative products that bind all Indonesian citizens to comply with them.

Other research results according to Firmansah, B. (2020) tax disputes occur due to changes in the tax collection system from self assessment to official assessment. These changes occur when the tax authority conducts an inspection or verification of the taxpayer. Darono, A. (2020) and Sunarya, A. (2018). revealed that tax audits are tax law enforcement actions that most often result in tax disputes. The question that arises then is, if the tax audit is one of the law enforcement actions that should be the final "executors" in tax law enforcement, why does the result of the tax audit decision seem not yet final and (still) debatable? Or is the tax dispute a form of coercion of power possessed by the tax examiner?

The limitations of the results of previous research on tax disputes make it a separate motivation for researchers to conduct further research. Various theories and literature that discuss the issue of tax disputes in the Indonesian taxation system so far have not been sufficient to answer the various questions that arise in researchers. These studies still rely on a theoretical framework and structural analysis from the subjective point of view of a researcher so that the basic essences of the tax dispute phenomenon are not presented in a "whole" manner. Therefore, in this study, researchers conducted a study that was not only trapped in the "structure", but research that was able to present tax disputes in a purer essence.

Tax examiners are used as research subjects in the hope that they can provide meaning about tax disputes from their perspective. Researchers conducted a (new) research on tax disputes that had never been done by previous researchers. The tax examiner as the party who feels the direct "experience" of tax disputes is the right research subject. Armed with experience of direct involvement with tax disputes, it is hoped that the tax examiners have a background of adequate knowledge and understanding.

\section{THEORITICAL REVIEW}

\section{Tax Disputes in Indonesia}

"The long (still) winding road" is an expression used by researchers to describe the long process in tax disputes. There are still many problems and procedures that must be faced by the disputing parties. Taxpayers as the applicant for tax disputes and DGT as the "opponent" have to go through various kinds of formal taxation procedures and procedures that are quite complicated, spend a lot of time and energy, and even have to set aside costs that can be said to be not small. Tax disputes are a long and tortuous process because tax disputes do not only occur during the objection process or appeal process by the taxpayer in the tax court, but long before that.

\section{Tax audits}

The tax examiner will conduct tests on books, documents, records and other evidence that reflect the bookkeeping (accounting), and present the tax obligations of a taxpayer, in the tax audit process. The tax audit process at this stage is referred to as the testing and verification process (PMK No.17/2013). At this stage the tax examiner is given a time limit4 to carry out the testing and verification process. Such testing must also be carried out using inspection methods, techniques, and procedures based on the guidelines set out in the inspection standards.

After the testing and verification process is carried out, the findings of the tax examiner that have not been or cannot be refuted by the taxpayer will be stated in the Notification of Examination Results (SPHP). The SPHP describes the number of audit findings, administrative sanctions, and the legal basis for making corrections. Taxpayers will be given the opportunity to respond to the findings in the SPHP accompanied by supporting evidence. This process determines whether the findings of the examination are approved by both parties or not. If there is no dispute or difference of opinion between the tax examiner and the taxpayer, the tax dispute will most likely not occur. However, if in the final discussion of the results of the audit there are still differences of opinion that have not found a "common ground", then the results of the tax audit will have a great chance of becoming a tax dispute and that's when the long journey begins.

\section{Tax Collection System}

The tax collection system is an approach from the subjective side of who is authorized by law to carry out tax collection tasks. The tax collection system is divided into three parts, namely: 
a. Self-Assessment System, which is a tax collection system that gives taxpayers the confidence to calculate/calculate, pay, and report the amount of tax owed on themselves based on tax laws and regulations.

b. Withholding Tax System, is a tax collection system that gives confidence to Taxpayers to calculate, pay, and report the amount of tax payable to third parties who are counterparties to transactions based on tax laws and regulations.

c. Official Assessment System. This tax collection system authorizes the government (fiskus) to calculate and determine the amount of tax owed to taxpayers in accordance with the provisions of the Taxation Law.

\section{Barriers to Collection}

Taxes There are many obstacles in the tax collection process, namely in the form of resistance to avoid or evade taxation, because there is a stigma of "involuntary" or "burdening burden" in paying taxes.

\section{Tax Dispute Resolution with Tax Collectors}

Settlement of tax disputes through the Tax Court is regulated in Chapter IV Article 34 to Article 42 of Law Number 14 of 2002, including the arrangement of legal remedies for Judicial Review to the Supreme Court. Against a decision, a lawsuit or an appeal letter is filed. The current Tax Court is historically a refinement of the previous Tax Court institution, namely the Tax Dispute Settlement Agency (BPSP). To overcome the shortcomings and weaknesses of BPSP, in particular the application of the judicial power system with a tiered examination to the Supreme Court, the Tax Court applies a judicial review to the Supreme Court.

The duties and authorities of the Tax Court in resolving tax disputes are examining and deciding disputes over objection decisions, unless otherwise stipulated by the applicable laws and regulations. The Tax Court in the lawsuit examines and decides on disputes over the implementation of Tax collection on rectification decisions or other decisions, as referred to in Article 23 paragraph 2 of Law Number 6 of 1983 concerning General Provisions and Tax Procedures which have been amended several times, most recently by Law Law Number 16 of 2000 and the applicable tax laws and regulations.

Based on the above understanding, the elements of a tax dispute are:

a. Disputes in the field of taxation

b. There are two parties, namely the taxpayer and the tax official.

c. There is a decision issued by the Tax Officer.

d. There is an opportunity/right to file an appeal or lawsuit

e. An appeal or lawsuit is filed with the Tax Court.

f. Based on laws and regulations in the field of taxation.

Tax dispute legal remedies related to tax audits, investigations and collections in the tax law try to place the rights and obligations of taxpayers in balance with the tax authorities (tax officials), although the tax authorities have a number of powers in supervising and enforcing tax provisions through research, examination, investigation. and tax collection. The Tax Law also gives taxpayers the right to take legal action if there is a tax dispute, both formal and material.
Legal efforts can be carried out by taxpayers, whether the dispute resolution is carried out at the Directorate General of Taxes itself, or the settlement is outside the Directorate General of Taxes, namely the Tax Court and the Supreme Court. In addition to taxpayers, the Director General of Taxes can also take legal remedies in terms of judicial review, which is an extraordinary legal remedy. Legal remedies that can be taken by third parties, in terms of filing a rebuttal submitted to the District Court.

Each of the legal remedies that have these procedures and procedures often results in legal efforts to achieve justice being stopped, because they do not meet formal provisions. For this, an understanding of the procedures and procedures for filing and settling legal remedies is absolutely necessary.

In tax law in Indonesia, the settlement of tax disputes is resolved through several channels/institutions, namely objections, appeals, lawsuits and judicial reviews. Provisions on certain institutions to resolve tax disputes are strictly regulated in formal tax law.

These legal remedies can be described as follows:

\section{a. Objection}

The issue of objection is the right of the taxpayer, as regulated in Article 25 paragraph (1) letter a of the KUP Law (General Provisions and Tax Procedures), that the taxpayer can file an objection only to the Director General of Taxes on an underpaid tax assessment. Tax Objections in filing have risks, as described in Article 29 paragraph (9), where in the event that the Taxpayer's objection is rejected or partially granted, the Taxpayer is subject to administrative sanctions in the form of a fine of $50 \%$ of the total tax based on the tax objection decision, reduced by tax paid before filing an objection. In the explanation of Article 29 paragraph (9) it is stated, "In the event that the objection, the Taxpayer is rejected or partially granted and the Taxpayer does not file an appeal, the amount of tax based on the decision of the objection is reduced by the tax paid before filing the objection must be paid in no later than 1 (one) year. ) months from the date of issuance of the Decision Letter of Objection, and Billing by Forced Letter will be carried out.

One of the inspection products is the issuance of a tax assessment letter (SKP). If the taxpayer does not agree with the SKP, by reason of a material dispute, the taxpayer can take legal action in the form of an objection. Objection to the tax determination is the right of the taxpayer which is guaranteed by law in the context of justice in fulfilling tax obligations. An objection can be submitted by the taxpayer if the taxpayer is not satisfied with the tax determination made by the tax authorities. The existence of the right to file an objection creates a balance between the taxpayer and the tax authorities, and ensures that the taxpayer is protected from the authority of the tax authorities.

In Indonesian tax law, the provisions regarding objections are regulated in several tax laws, namely the KUP Law (General Provisions and Tax Procedures), the PBB Law (Land and Building Taxes), the BPHTB Law (Taxes for Acquisition of Land and Building Rights). , and the PDRD Law (Regional Taxes and Retributions). The regulation of central tax objections is regulated in three laws that are adjusted to the type of central tax that is objected to, while the type of objection to local taxes is regulated in the PDRD Law and regional regulations that impose local taxes 
on a province, district or city. The submission of an objection must meet the following requirements:

1) Submitted in writing in Indonesian;

2) State the amount of tax payable or the amount of tax withheld or collected, or the amount of loss according to the calculation of the taxpayer, accompanied by the reasons that form the basis of the calculation; What is meant by the reasons that form the basis for the calculation are clear reasons and attached with a photocopy of the tax assessment letter, proof of collection, or proof of withholding.

3) One tax objection letter is submitted only for 1 (one) tax assessment letter, or 1 (one) tax collection.

\section{Appeal}

According to the meaning contained in Article 1 point 6 of Law Number 14 of 2002 concerning the Tax Court, an appeal is a legal remedy that can be taken by a Taxpayer or a tax insurer against a decision that can be appealed based on the applicable tax laws and regulations. In accordance with the provisions of Article 27 of the KUP Law (General Provisions and Tax Procedures), Taxpayers may submit an appeal only to the tax court against the Objection Decision, as referred to in Article 26 paragraph (1) of the KUP Law (General Provisions and Tax procedure). Thus, an appeal can only be filed on the Decision Letter of Objection.

Legal remedies for objections in filing an appeal must also meet the requirements, which are submitted within 3 months from the date of receipt of the decision being appealed, using Indonesian, one letter of appeal for one decision being appealed, stating clear reasons, attaching a copy of the decision being appealed pay $50 \%$ of the amount owed on the appeal decision. Those who can file an appeal are Taxpayers, heirs of the Taxpayer, a company management and the Taxpayer's attorney.

The objection decision letter issued by the Director General of Taxes for the type of central tax or issued by the regional head or appointed official, is submitted to the taxpayer for proper implementation. If the Taxpayer does not agree with the contents of the Decision Letter of Objection he/she receives, he/she has the right to file an appeal to the tax court appointed or determined by the tax law.

\section{Claims and Disclaimers}

a. Lawsuit

In relation to collection actions, the tax provisions give the taxpayer the right to take legal action in the form of a lawsuit. A lawsuit can also be made against decisions relating to the implementation of other tax decisions. In addition to lawsuits, as a result of collection actions, it is also possible for legal remedies in the form of rebuttals that can be submitted by third parties. A lawsuit is a legal action that can be taken by a taxpayer or tax insurer against the implementation of tax collection, or against decisions that can be filed according to the applicable tax laws and regulations. Similar to an appeal, the filing of a lawsuit must also meet the requirements, namely that it is filed within 14 days from the date of collection, submitted in writing using the Indonesian language. In the case of anyone who can file a lawsuit, which consists of the plaintiff, the plaintiff's heirs, an administrator, or the plaintiff's attorney.

Generally, a lawsuit is filed by a taxpayer who feels aggrieved by the actions of the tax authorities in carrying out tax collection actions against both the taxpayer and the tax guarantor. The lawsuit is strictly regulated in Indonesian tax law to protect the interests of the Taxpayer from the tax authorities' actions which according to the Taxpayer are not in accordance with the provisions of the applicable tax laws. The right of the taxpayer to file a lawsuit is regulated in the KUP Law (General Provisions and Tax Procedures) for all types of central taxes. In addition, because this lawsuit was made by the taxpayer related to the implementation of tax collection, this is also regulated in the Tax Dispute Settlement Agency Law (BPSP). Given that the BPSP Law also applies as the legal basis for local tax collection, local taxpayers who feel aggrieved by the tax authorities in the implementation of local tax collection can also file a lawsuit.

\section{b. Rebuttal}

Third parties who feel aggrieved in the implementation of tax collection with a Forced Letter are basically protected under Indonesian tax law. In the above circumstances, third parties have the right to take legal action against the tax authorities' actions. This is manifested in the form of a rebuttal to the ownership of the confiscated goods. According to Article 38 of the Law on General Provisions and Tax Procedures Number 6 of 1983, third party objections to the ownership of confiscated goods can only be submitted to the District Court. The District Court receiving the rebuttal shall notify the official authorized to carry out tax collection in writing. The official suspends the implementation of tax collection only on goods whose ownership is disputed since receiving the rebuttal notification. A third party's objection to the ownership of the confiscated goods cannot be submitted after the auction has been carried out.

\section{c. Judicial Review}

The review is an extraordinary legal remedy that can be submitted by the Taxpayer, and is the last legal remedy in tax provisions. The final process of a judicial review tax dispute is filed if the party concerned is not/not satisfied with the court's decision, then the disputing party can file a judicial review to the Supreme Court through the Tax Court, and it can only be submitted once. Based on Article 77 paragraph 3 of Law Number 14 of 2002 concerning the Tax Court, the disputing parties may file a case against the decision of the Supreme Court. The submission of a review can be submitted by the disputing parties, meaning that it can be carried out by the Taxpayer or the Directorate General of Taxes.

Reasons for Review:

1. The Tax Court's decision is based on a lie or deception;

2. There is new and important written evidence, which is decisive;

3. Granted something that is not demanded or more than what is required;

4. There is a part of the claim that has not been decided without considering the reasons.

\section{System and Application Design}

The design process in this research is done conceptually, namely at this stage planning and database creation are carried out by creating interconnected data relations and determining the relationship between one attribute and another using the UML method. Next, determine the actors involved in the form of a use case diagram and what actions can be taken. Then compose a flow diagram of all the functions that exist in the information system, 
translate it into programming code and implement it. Design of Web-Based Decision File Management Information System at the Tax Court of the Republic of Indonesia.

\section{System planning}

The initial stage of system design is the translation of data from the previous data processing program into tables in the database. A database is a collection of logically related data and is a description of that data, designed to meet the information needs of an organization. After determining the tables that are entered in the form of a database, then the relations for each table are then arranged.

\section{RESEARCH METHODS}

This study uses a qualitative approach with phenomenological research methods. Qualitative research is used because there is a problem or social issue that needs to be explored in this study, namely the issue of tax disputes. According to Husain, T. (2017) an exploration is needed because of the need to study certain groups, identify variables that are not easy to measure or to listen to faint sounds. Qualitative research in this case is also used to follow up on various kinds of quantitative research and previous qualitative research.

The data collection method used in this study was interviews. Interviews in this study were conducted in an unstructured format. Researchers do not strictly rely on a list of interview questions, but move to follow the feedback of informants while still holding onto the research issue. The interview topic raised in this study is about the issue of tax disputes. This topic reveals in detail the "what" and "how" of tax disputes for tax auditors. In this interview process, the researcher tries to enter the conceptual world of the informant so that the researcher understands and understands the informant's point of view on the interview topic being discussed. The interviews took place continuously until no new perspectives were found by the informants on the topic.

After the data collection process is complete, the researcher performs a data analysis stage called a description of the phenomenon. At this stage, the researcher fully describes the phenomena experienced by the informants. All recorded in-depth interviews with informants were transcribed into written language for easy analysis. The spoken language of the interviews with the informants was transcribed in its entirety into a text.

\section{RESULTS AND DISCUSSION}

In this section, a description of the essence of tax disputes will be presented in the perspective of the tax examiner. This description of the essence is the final result of data analysis and is the culmination of the study of phenomenology. This essence description is the result of the construction of a comprehensive description of the twelve themes obtained in the results of the previous analysis. The essence of this meaning is a combination of textural descriptions and structural descriptions obtained during the research process.

Civilization, I. L. (2019) state that negotiation is "a form of decision making in which two or more parties talk with another in an effort to resolve their opposing interests". Tax negotiations between taxpayers and the tax authorities have also been carried out in several countries Sunarya, A. (2018). In China, for example, taxpayers must negotiate with the Tax Authority if they want to charge higher fees when tax rates are high in the period after the tax holiday Ahmad, D. (2020).

Furthermore, the concept of "negotiation" of taxation has essentially existed and is embedded in the "spirit" or "soul" of the self-assessment system used in the Indonesian Taxation System. Self-assessment has indirectly provided space for "negotiations" for taxpayers to be able to calculate and calculate the amount of tax that must be paid themselves. The choice of the use of accounting methods, measurement techniques and other accounting policies in the books used as the basis for determining the tax payable, for example. This is a form of "negotiation" provided in the Indonesian Tax System. These various options and flexibility are a means for taxpayers to "negotiate" with the Tax Authority (DGT) within the framework of self-assessment without having to violate or violate existing regulations.

Likewise, in the tax audit process, although it is included in law enforcement actions, tax audits are also interpreted as a form of tax "negotiation". These "negotiations" occurred when the Tax Authority offered relief in the implementation of tax audits, especially in the gray area issue Ramadhan, A. R. F. P. (2017) and in the substance of potential tax obligations Aslama, I. D. (2017). The meaning of "negotiation" becomes increasingly clear when the tax audit cannot show the strict nature of its execution. When the tax audit has not been able to fully demonstrate its discretionary function, there is (still) "space" of freedom given to taxpayers to accept or reject the final tax audit results.

When the tax audit (still) has not been able to complete its duties as executor and final negotiator of the self-assessment system, the Indonesian tax law provides another legal "negotiation" space. Further "negotiation" spaces in an effort to get an "agreement" in the final goal of "satisfaction", a sense of justice and legal certainty. Based on the description above, the researcher through this phenomenological study then describes the meaning of tax disputes as a taxation phenomenon in Indonesia from the perspective of the tax examiner in the essence of the meaning of "Unfinished Negotiations".

The practice of tax disputes must be an example for the wider community of how tax trust in the government must be built in order to uphold the principle of justice. That the tax law must be treated fairly for every citizen. If justice is applied firmly, every Indonesian citizen will always be "directed" to be in the "corridor" of tax compliance. In previous research, it was revealed that tax compliance in Indonesia is still weak, one of which is because taxpayers who do not comply have not received strict sanctions Nugraha, F. A., Muryono, S., \& Utami, W. (2021). Mayasari, I. D. A. D., \& Rudy, D. G. (2021) asserted that this was a failure of DGT's tax reform in the field of law enforcement.

Referring to the results of the study, in the event that the difference of opinion is still in an ideal context (still in accordance with the existing rational theory), tax examiners perceive tax disputes as a normal and natural process. However, when the tax dispute is already in the category of "policy negotiation" and "authority negotiation", the tax inspector actually perceives it with feelings of sadness, empathy, disappointment and helplessness. Why should the two "negotiations" be perceived in such a way by tax auditors? Why is it that the tax examiner has to feel the 
pressure from the existing tax dispute process, not the taxpayer who should be pressured?

This "pressure" occurs because in the current state of the Indonesian tax system, tax auditors are still in a "weak" position. The Tax Auditor as one of the holders of the law enforcement mandate from the tax authority (still) does not have "full" power in imposing its authority on taxpayers through tax audit legal products. The discretion of the tax examiners currently seems to be "half-hearted". This can be seen from the research findings which state that there is still a big "hole" for anyone who wants to go to tax disputes. Even though the tax auditors have performed their duties in accordance with the applicable rules and regulations, there is still room for taxpayers to file a tax dispute or "sue" the tax auditor.

On the reflection of the researcher, if the tax examiners want to be in great discretionary power as said by Muhammad (2013) "they possess a great deal of discretionary power", then give them "discretionary" space and authority "without a doubt". If tax examiners want to function as tax law enforcement officers who work firmly, then give them the power and ability to carry out comprehensive executions, not just "half-hearted" discretion. Do not give "space" and legal loopholes that can be used by a handful of parties to "escape" from the obligation to pay taxes, especially from law enforcement processes. Thus, there are no more parties trying to consider "playing" with the tax dispute process.

Thus, in the process of resolving tax disputes, taxpayers have the right to file various legal remedies based on the provisions of the law. Taxpayers can file objections to the Directorate General (Dirjen) of Taxes and appeal to the Tax Court, and can file extraordinary legal remedies, namely reconsideration (if eligible) to the Supreme Court. In the process of resolving tax disputes, not only taxpayers must spend their time and energy to follow the process, the reviewers of objections are also very much needed. Moreover, the number of tax disputes continues to increase every year, while human resources dealing with tax objections are still very limited.

\section{CONCLUSION}

Tax disputes are not an "empty space" without meaning, there are various hidden meanings in this taxation phenomenon. The diversity of meanings that also contribute and present a new perspective for anyone who wants to see the phenomenon of tax disputes more "closely". In addition to verifying the findings in the previous literature, this study also reveals new meanings about tax disputes that have not been previously disclosed. This study also found many values that can be learned from the tax dispute process that occurred in Indonesia so that further studies are needed. "Values" that can provide perspectives in the study of science are not only from the disciplines of accounting and taxation, but from various other aspects of knowledge.

The researcher also tries to reflect on the findings of research on tax disputes with the issue of tax compliance and tax behavior in Indonesia. In the "material negotiation" and "formal negotiations" groups, for example, the researcher considers that tax disputes in this group will not arise if the taxpayers carry out their tax obligations in full compliance with the principles. If the Taxpayer carries out his bookkeeping (accounting) obligations properly and in an orderly manner in accordance with existing provisions, the substantive differences of opinion should not be prolonged. Likewise with tax disputes that occur in fiscal juridical differences of opinion. The researcher also considers that the tax dispute in the "formal negotiation" group occurs because the taxpayers' understanding of a tax regulation is still low. This low understanding then causes the emergence of multiple interpretations in implementing tax provisions.

In contrast to the previous findings, in the "authority negotiation" group, it was revealed that tax disputes occur precisely because taxpayers have good knowledge in the field of taxation. Taxpayers who are "disputed" in this group are taxpayers who can use their knowledge to carry out tax planning or even tax avoidance. This seems to verify the findings of several previous studies in attribution theory (McKerchar and Evans, 2009, Palil and Ahmad, 2013, and Munawaroh et al., 2014), which stated that better knowledge can also encourage taxpayers to do tax evasion. This knowledge is in line with the development of information and technology, including tax information.

Specifically related to the tax audit process and the tax dispute process, the Government of the Republic of Indonesia through the DGT must be able to apply the existing tax regulations strictly. The tax audit process must be carried out with a transparent and clear procedure. Tax law enforcement must be carried out properly and without "selective discrimination". If there is equal law enforcement among taxpayers, it is hoped that a psychological social situation will be created among taxpayers that fulfills a sense of justice so as to increase tax compliance and create better tax behavior. This gives hope that the tax dispute process in the future will truly become a process of resolving differences in accordance with its function. A tax dispute process that can uphold a sense of justice and promote legal certainty towards a more trusted and dignified Indonesian tax system.

The design of a web-based File Management Information System at the Tax Court can assist the online and real-time decision file management process. This is because the relevant officers can record and manage decision files in a more effective and efficient way which includes data collection of decision files received and decision files borrowed.

Settlement of tax disputes through the Tax Court is regulated in Chapter IV Article 34 to Article 42 of Law Number 14 of 2002, including the arrangement of legal remedies for Judicial Review to the Supreme Court. Against a decision, a lawsuit or an appeal letter is filed. In carrying out their tax obligations, taxpayers are often dissatisfied with the implementation of the law implemented by the Fiskus (Tax Collector), either because of the issuance of tax assessments, or because of the implementation of billing based on the provisions of the applicable law. Tax objections arise because there are provisions on tax agency decisions that are considered unfair by taxpayers. The tax law itself confirms what legal remedies can be taken by taxpayers to resolve tax disputes that arise, whether the dispute resolution is carried out at the Directorate General of Taxes itself, or the settlement is carried out outside the Directorate General of Taxes, namely in the Tax Court and the Tax Court. Great. In addition to taxpayers, the Director General of Taxes can also take legal remedies in terms of judicial review, which is an extraordinary legal remedy. Legal efforts can be made by a third party, in the case of filing a rebuttal submitted to the District Court. 


\section{SUGGESTION}

1. Continually conducting counseling and improving supervision, as well as implementing good governance, especially for the tax apparatus, and at the same time carrying out clear, fair and balanced legal development and enforcement through instruments.

2. Laws are generally coercive in nature, but at the level of implementation it is possible to encounter many obstacles in the tax collection process, which often lead to disputes. For this reason, continuous efforts are needed to increase awareness and compliance of the taxpayers themselves.

Identify the constructs of a Journal - Essentially a journal consists of five major sections. The number of pages may vary depending upon the topic of research work but generally comprises up to 5 to 7 pages. These are:

1) Abstract

2) Introduction

3) Research Elaborations

4) Results or Finding

5) Conclusions

In Introduction you can mention the introduction about your research.

\section{IDENTIFY, RESEARCH AND COLLECT IDEA}

It's the foremost preliminary step for proceeding with any research work writing. While doing this go through a complete thought process of your Journal subject and research for it's viability by following means:

1) Read already published work in the same field.

2) Goggling on the topic of your research work.

3) Attend conferences, workshops and symposiums on the same fields or on related counterparts.

4) Understand the scientific terms and jargon related to your research work.

\section{WRITE DOWN YOUR STUDIES AND FINDINGS}

Now it is the time to articulate the research work with ideas gathered in above steps by adopting any of below suitable approaches:

\section{A. Bits and Pieces together}

In this approach combine all your researched information in form of a journal or research paper. In this researcher can take the reference of already accomplished work as a starting building block of its paper.

Jump Start

This approach works the best in guidance of fellow researchers. In this the authors continuously receives or asks inputs from their fellows. It enriches the information pool of your paper with expert comments or up gradations. And the researcher feels confident about their work and takes a jump to start the paper writing.

\section{B. Use of Simulation software}

There are numbers of software available which can mimic the process involved in your research work and can produce the possible result. One of such type of software is Matlab. You can readily find Mfiles related to your research work on internet or in some cases these can require few modifications. Once these Mfiles are uploaded in software, you can get the simulated results of your paper and it easies the process of paper writing.

As by adopting the above practices all major constructs of a research paper can be written and together compiled to form a complete research ready for Peer review.

\section{GET PEER REVIEWED}

Here comes the most crucial step for your research publication. Ensure the drafted journal is critically reviewed by your peers or any subject matter experts. Always try to get maximum review comments even if you are well confident about your paper.

For peer review send you research paper in IJSRP format to editor@ijsrp.org.

\section{IMPROVEMENT AS PER REVIEWER COMMENTS}

Analyze and understand all the provided review comments thoroughly. Now make the required amendments in your paper. If you are not confident about any review comment, then don't forget to get clarity about that comment. And in some cases there could be chances where your paper receives number of critical remarks. In that cases don't get disheartened and try to improvise the maximum.

After submission IJSRP will send you reviewer comment within 10-15 days of submission and you can send us the updated paper within a week for publishing.

This completes the entire process required for widespread of research work on open front. Generally all International Journals are governed by an Intellectual body and they select the most suitable paper for publishing after a thorough analysis of submitted paper. Selected paper get published (online and printed) in their periodicals and get indexed by number of sources.

After the successful review and payment, IJSRP will publish your paper for the current edition. You can find the payment details at: http://ijsrp.org/online-publication-charge.html.

\section{CONCLUSION}

A conclusion section is not required. Although a conclusion may review the main points of the paper, do not replicate the abstract as the conclusion. A conclusion might elaborate on the importance of the work or suggest applications and extensions.

\section{APPENDIX}

Appendixes, if needed, appear before the acknowledgment. 


\section{ACKNOWLEDGMENT}

The preferred spelling of the word "acknowledgment" in American English is without an "e" after the "g." Use the singular heading even if you have many acknowledgments.

\section{REFERENCES}

[1] Adhyaputra, A. D. (2020). Penerapan Good Governance Dalam Rekrutmen Hakim Pengadilan Pajak (Doctoral dissertation, Universitas Brawijaya).

[2] Ahmad, D. (2020). Analisis Kebijakan Insentif Pajak Penghasilan Atas Biaya Penelitian Dan Pengembangan Dalam Peningkatan Kualitas Sumber Daya Manusia (Doctoral Dissertation, Universitas Brawijaya).

[3] Ambarwati, D., \& Senduk, M. F. (2019). Formulasi Pengaturan Waktu Kerja Bagi Pengemudi Transportasi Jalan Berbasis Aplikasi Online. In Seminar Nasional \& Call For Papers Magister Hukum Uns 2019 (Pp. 464-478). Magister Hukum Universitas Sebelas Maret.

[4] Aslama, I. D. (2017). Pengaruh Mekanisme Good Corporate Governance Dan Profitabilitas Terhadap Tax Avoidance Studi Pada Perusahaan Pertambangan Berbasis Syariah Yang Terdaftar Di Bursa Efek Indonesia Tahun 2011-2015 (Doctoral Dissertation, Fakultas Ekonomi Dan Bisnis Unpas Bandung).

[5] Civilization, I. L. (2019). Modernisasi Peradilan Tata Usaha Negara Di Era Revolusi Industri 4.0 Untuk Mendorong Kemajuan Peradaban Hukum Indonesia Modernization Of The State Administrative Jurisdiction In The Era Of The Industrial.

[6] Darono, A. (2020). Integrasi Informasi Dan Cooperative Tax Compliance: Analisis Institusional Komparatif. Jurnal Bppk: Badan Pendidikan Dan Pelatihan Keuangan, 13(2), 87-99.

[7] Firmansah, B. (2020). Analisis Kesiapan Otoritas Pajak Dalam Pemajakan Atas Ekonomi Digital. Jpsi (Journal Of Public Sector Innovations), 5(1), 1322.

[8] Firmansyah, A., Irawan, F., Jadi, P. H., Febrian, W., Fasita, E., Sismanyudi, D., \& Soekarno, R. S. (2021). Pelatihan Implementasi Praktik Transfer Pricing dari Sudut Pandang Akuntansi, Pajak, dan Hukum. KUAT: Keuangan Umum dan Akuntansi Terapan, 3(1), 1-7.

[9] Hidayah, A. (2019). Perancangan sistem inventaris tanah berbasis website geographic information system (studi kasus: balai desa podourip kebumen) (doctoral dissertation, university of technology yogyakarta).

[10] Husain, T. (2017). Pengaruh Tax Avoidance Dan Kualitas Audit Terhadap Manajemen Laba. Jurnal Online Insan Akuntan, 2(1), 137-156.

[11] Mayasari, I. D. A. D., \& Rudy, D. G. (2021). Urgensi Rekonstruksi Pengaturan Praktek Perjanjian Perdagangan Melalui E-Commerce. Jurnal Komunikasi Hukum (Jkh), 7(1), 235-251.
[12] Nugraha, F. A., Muryono, S., \& Utami, W. (2021). Membangun Sistem Informasi Penggunaan Tanah Berbasis Bidang Tanah Di Desa Blimbing Kecamatan Gatak Kabupaten Sukoharjo. Tunas Agraria, 4(1), 146-157.

[13] Pratama, G. (2020). Perancangan Sistem Informasi Manajemen Berkas Putusan Berbasis Web di Pengadilan Pajak Republik Indonesia. Senamika, 1(1), 326-343.

[14] Purnamasari, R., Meutia, I., \& Yuniartie, E. (2018). Analisis Perbandingan Tingkat Konservatisme Akuntansi Pada Bank Umum Syariah Dan Bank Umum Konvensional Di Indonesia. Akuntabilitas, 12(1), 41-56.

[15] Ramadhan, A. R. F. P. (2017). Implementasi Sistem Pajak Online (E-Tax) Dalam Meningkatkan Pendapatan Asli Daerah Kota Malang (Studi Pada Pajak Hotel Dan Restoran Di Dinas Pendapatan Daerah Kota Malang) (Doctoral Dissertation, Universitas Brawijaya).

[16] Samsudin, H., Indra Gunawan, C., \& Sasmito, C. (2019). Hasil Cek Similarity: Membongkar Relasi Kekuasaan Oligarki Di Kota Batu: Studi Kasus Penyalahgunaan Kekuasaan Dalam Pemberian Keringanan Pajak Dan Korupsi Kebijakan Pt Bwr. Membongkar Relasi Kekuasaan Oligarki Di Kota Batu: Studi Kasus Penyalahgunaan Kekuasaan Dalam Pemberian Keringanan Pajak Dan Korupsi Kebijakan Pt Bwr, 16(2), 210-227.

[17] Sunarya, A. (2018). Hasil Cek Plagiasi Buku: Reformasi Birokrasi Administrasi Pelayanan Pajak Kendaraan Bermotor Berbasis.

[18] Sunarya, A. (2018). Reformasi Birokrasi Administrasi Pelayanan Pajak Kendaraan Bermotor Berbasis Mobile Technology Di Kantor Bersama Samsat Provinsi Jawa Timur.

[19] Syamsuddin, S. (2021). Dampak Covid 19 Terhadap Target Dan Realisasi Penerimaan Pajak Hotel Dan Restoran Di Kota Makassar. Journal of Business Administration (JBA), 1(1), 5-14.

[20] Usman, S., \& Lana, B. (2019). Analisis Penerimaan Pajak Kendaraan Bermotor Terhadap Pendapatan Asli Daerah Provinsi Maluku Utara Hibualamo: Seri Ilmu-Ilmu Sosial Dan Kependidikan, 3(1), 38-44.

[21] Yostiawan, L. (2020). E-CRM System Berbasis Web Di Sekretariat Pengadilan Pajak. Senamika, 1(1), 387-393.

[22] Yunus, R. M., \& Cartinah, T. (2018, October). Rancang Bangun Surat Pemberitahuan Pajak Daerah (E-Sptpd) Berbasis Web Pada Badan Keuangan Dan Aset Daerah Kabupaten Majalengka. In Prosiding Industrial Research Workshop And National Seminar (Vol. 9, Pp. 295-302).

\section{AUTHORS}

First Author - Joni, S.S.T, BKP, Institut STIAMI, joni.jovindo@gmail.com 